\title{
PERBEDAAN KEMAMPUAN BERCERITA MENGGUNAKAN MEDIA AUDIOVISUAL DENGAN AUDIO SISWA KELAS VII SMP BUDI MURNI 4 MEDAN
}

\author{
Citrael Waruwu, Losten Tamba, Adelina Ginting \\ 1. Universitas Katolik Santo Thomas \\ 2. Universitas Katolik Santo Thomas \\ 3. Universitas Katolik Santo Thomas \\ Citrael.waruwu@gmail.com
}

\begin{abstract}
Abstrak. Penelitian ini bertujuan untuk mengetahui perbedaan kemampuan bercerita menggunakan media audiovisual dengan audio. Penelitian ini dilakukan di SMP Budi Murni 4 Medan pada bulan Agustus 2019. Subjek penelitian ini berjumlah 60 siswa. Metode yang digunakan dalam penelitian adalah metode eksperimen static group comparison design yang dilaksanakan pada dua kelompok. Instrumen yang digunakan untuk menjaring data adalah tes essay dalam bentuk penugasan yaitu kemampuan menulis bercerita kembali. Pengujian hipotesis dilakukan dengan menggunakan uji "t". Berdasarkan hasil pengolahan data statistik yang menunjukkan bahwa kemampuan menulis bercerita kembali dengan menggunakan media audio termasuk dalam kategori baik dengan nilai ratarata 76.86. Sedangkan kemampuan bercerita menggunakan media audiovisual termasuk dalam kategori baik dengan nilai rata-rata 80.2. Selanjutnya, pengujian hipotesis menunjukkan $t_{\text {hitung }}$ adalah 2.08 kemudian dikonsultasikan dengan tabel $\mathrm{t}$ pada taraf signifikan $\alpha=0.05$ dengan df $=58$ adalah 2.01. Oleh karena $t_{\text {hitung }}$ yang diperoleh lebih besar dari $t_{\text {tabel }}$ yaitu $2.08>$ 2.01 maka terbukti bahwa hipotesis nihil $\left(\mathrm{H}_{0}\right)$ ditolak dan hipotesis alternatif $\left(\mathrm{H}_{a}\right)$ diterima. Maka, dapat disimpulkan bahwa media audiovisual dengan audio berpengaruh signifikan terhadap kemampuan bercerita siswa kelas VII SMP Budi Murni 4 Medan. Implikasi penelitian ialah siswa lebih mudah menceritakan kembali melalui media audiovisual dengan audio berdasakan pengamatan terhadap video yang ditayangkan, yang menjelaskan tentang pengertian, ciri-ciri, struktur teks cerita fantasi, disertai dengan contoh yang videonya bisa diputar berulang-ulang. Penelitian menyarankan bahwa kemampuan bercerita perlu ditingkatkan melalui media yang sesuai.

Kata Kunci: media pembelajaran, audiovisual, audio, kemampuan bercerita
\end{abstract}

Abstract. This research aims to know the difference in the ability to tell a story using audiovisual media with audio. This research was conducted at the SMP Budi Murni 4 Medan in August 2019. The subject of this study numbered 60 students. The methods used in the study are experimental methods of static group comparison design implemented on two groups. The instruments used to trawl data was in the form of essay test commissioned namely writing skills to tell stories again. Hypothesis testing is done using the " $t$ " test. Based on the results of the processing of the statistical data which shows that the ability to write back to tell a story using the media audio included in the well with the average value. While the ability to tell a story using audiovisual media are included in the category either by the average value. Furthermore, the hypothesis testing shows thitung is 2.08 then consulted with tables on the extent the significant $\mathrm{t} \alpha=0.05$ with $\mathrm{df}=58$ is 2.01. Therefore thitung is obtained is greater than ttabel i.e. $2.082 .01>$ then proved that the zero hypothesis $(\mathrm{H} 0)$ is rejected and the alternative hypothesis $(\mathrm{Ha})$ received. Thus, it 
can be concluded that the audiovisual media with audio effect significantly to the ability of SMP Budi Murni 4 Medan. The implication of the research is the student more easily recounting the audiovisual media with audio upon observation of the video aired, which describes.

Keywords: learning media, audiovisual, audio, story-telling

\section{PENDAHULUAN}

Kemampuan berkomunikasi penting dimiliki siswa, sebab kemampuan yang baik dalam berbahasa dapat membuat komunikasi berlangsung dengan lancar. Dalam Kurikulum 2013, standar kompetensi mata pelajaran Bahasa dan Sastra Indonesia mencakup aspek mendengarkan, berbicara, membaca, menulis, dan sastra. Sudah selayaknya aspek-aspek tersebut mendapat porsi yang seimbang dan dilaksanakan secara terpadu dalam satu tema. Salah satu aspek kemampuan berbahasa yang sangat penting peranannya dalam upaya melahirkan generasi masa depan yang cerdas, kritis, kreatif, dan berbudaya adalah kemampuan berbicara. Dengan menguasai kemampuan berbicara, siswa mampu mengekspresikan pikiran dan perasaannya secara cerdas sesuai konteks dan situasi pada saat dia sedang berbicara.

Namun, rendahnya kemampuan berbicara siswa bukanlah fenomena baru. Hal ini juga terjadi di kelas VII SMP Budi Murni 4 Medan. Berdasarkan pengamatan hampir seluruh siswa kelas VII SMP Budi Murni 4 Medan masih kurang terampil dalam aspek berbicara. Permasalahan rendahnya keterampilan berbicara siswa tidak didominasi oleh satu faktor saja. Dapat dikatakan bahwa ada dua faktor yang menyebabkan ketidakberhasilan pembelajaran berbicara, yaitu faktor eksternal dan faktor internal.

Termasuk faktor internal, yaitu di antaranya (1) siswa terlihat kurang percaya diri, (2) siswa sering terlihat lupa tentang isi cerita yang harus disampaikan, kata-kata atau ucapan yang disampaikan terputusputus, tidak jelas, dan (3) siswa yang tidak tampil (sebagai penyimak) terlihat tidak memperhatikan dan kurang berminat menyimak atau mendengarkan cerita temannya. Dari faktor eksternal, model pembelajaran, metode, media, atau sumber pembelajaran yang digunakan oleh guru memiliki pengaruh yang cukup signifikan terhadap tingkat kemampuan berbicara bagi siswa. Guru masih cenderung menggunakan teknik yang konvensional dan tidak menggunakan media yang menarik, guru hanya menggunakan buku panduan yang disediakan dari sekolah sehingga kegiatan pembelajaran berlangsung kurang menarik. Apabila ditelaah, keadaan tersebut mengindikasikan adannya suatu permasalahan yang bermuara kepada proses pembelajaran yang terjadi tidak menumbuhkan minat dan perhatian siswa. Pada akhirnya, dengan adanya kendala dalam proses pembelajaran, pencapaian hasil pembelajaran yang dilaksanakan tidak maksimal.

Dalam konteks demikian, diperlukan sesuatu yang menarik dalam menunjang proses pembelajaran guna mengundang minat belajar siswa. Salah satunya adalah dengan penggunaan media pembelajaran yang menarik, sehingga proses pembelajaran bisa berlangsung aktif, efektif, dan menyenangkan. Siswa tidak hanya diajak untuk belajar tentang bahasa secara rasional dan kognitif, tetapi juga diajak untuk belajar dan berlatih dalam konteks dan situasi tutur yang sesungguhnya dalam suasana yang interaktif, menarik, dan menyenangkan.

Penelitian ini difokuskan pada upaya untuk mengatasi salah satu faktor eksternal yang diduga menjadi penyebab rendahnya tingkat kemampuan siswa kelas VII SMP Budi Murni 4 Medan dalam berbicara, yaitu kurangnya kemampuan siswa dalam menceritakan kembali tentang pembelajaran secara terstruktur sesuai dengan kompetensi dasar bahasa Indonesia tingkat SMP/ MTS. Salah satu cara yang dapat mengatasi hal tersebut adalah penggunaan media yakni media audiovisual dengan audio. Audiovisual dengan audio sebagai media untuk dapat mencairkan suasana belajar dari yang biasa siswa dihidangkan dengan penjelasan-penjelasan guru saja beralih menjadi suasana belajar yang santai dan menarik. Selain memudahkan siswa untuk mencerna informasi secara visual, media ini juga memberi angin segar bagi siswa yang selama ini hanya disajikan dengan pembelajaran yang konvensional dengan harapan media film lebih menarik minat dan semangat siswa dalam mengikuti pembelajaran bercerita. 
Salah satu materi berbicara yang terdapat dalam Standar Kompetensi dan Kompetensi Dasar mata pelajaran Bahasa Indonesia SMP/MTs adalah bercerita dengan urutan yang baik, suara, lafal, intonasi, gestur, dan mimik yang tepat. Dalam kompetensi dasar tersebut tentu diperlukan suatu kemampuan berbicara sebagai aspek utama tujuan pembelajaran. Siswa diharapkan mampu menceritakan sebuah fenomena dengan susunan cerita yang runtut dan baik, lafal dan intonasi yang tepat, gestur dan mimikyang baik pula. Melalui penggunaan media audiovisual dalam pembelajaran bercerita dan instruksi kegiatan yang lebih terstruktur siswa akan mampu memetakan informasi yang didapat dari pemutaran film untuk diceritakan kembali di depan kelas.

Berdasarkan uraian yang telah dipaparkan, dapat disimpulkan bahwa faktor-faktor yang menyebabkan rendahnya kemampuan berbicara siswa adalah faktor internal dan eksternal. Berdasarkan hal tersebut, peneliti tertarik untuk melakukan penelitian dengan menggunakan media audiovisual dengan audio sebagai upaya meningkatkan kemampuan berbicara.

\section{HASIL PENELITIAN}

\section{Deskripsi dan Hasil Data Kelas Kontrol}

Berdasarkan hasil analisis diperoleh nilai rata-rata atau mean sebesar 76.86 , standar deviasi $=6.78$ dan standar error $=$ 1.25 .

\section{Deskripsi dan Hasil Data Kelas Eksperimen}

Berdasarkan hasil analisis diperoleh nilai rata-rata atau mean sebesar 80.2 standar deviasi $=5.49$ dan standar error $=$ 1.01. Berdasarkan tabel distribusi di atas, maka identifikasi kelas eksperimen dapat dikategorikan menjadi lima kelompok, Yaitu:

\section{Uji Normalitas Data Kelas Kontrol}

Berdasarkan hasil analisis harga yang paling besar diantara harga-harga mutlak selisih tersebut adalah $L_{0}=0.12$ dengan $\mathrm{n}=30$ dan taraf nyata $\alpha=0.05$ didapat $L_{\text {tabel }}=0.16$. Dengan demikian, $L_{\text {hitung }}<L_{\text {Tabel }}$ yaitu $0.12<0.16$ dan hal ini membuktikan bahwa data kontrol berdistribusi normal.

\section{Uji Normalitas Data Kelas Eksperimen}

Berdasarkan hasil analisis harga yang paling besar diantara harga-harga mutlak selisih tersebut adalah $L_{0}=0.15$ dengan $\mathrm{n}=30$ dan taraf nyata $\alpha=0.05$ didapat $L_{\text {tabel }}=0.16$. Dengan demikian, $L_{\text {hitung }}<L_{\text {Tabel }}$ yaitu $0.15<0.16$ dan hal ini membuktikan bahwa data eksperimen berdistribusi normal.

\section{Uji Homogenitas}

Kriteria pengujian adalah $H_{0}$ diterima jika $\quad F_{\text {hitung }}<F_{\text {tabel }}$ diambil dari $\mathrm{dk}$ pembilang adalah $\mathrm{dk}$ varians terbesar $\mathrm{dan} \mathrm{dk}$ penyebut adalah dk varians terkecil. Maka diperoleh $F_{\text {hitung }}=1.52$ dengan $\mathrm{dk}$ pembilang 30 dan dk penyebut 30 dari tabel F untuk $\alpha=0.05$ diperoleh $F_{\text {tabel }}$ untuk dk pembilang 30 dan $\mathrm{dk}$ penyebut 30 yaitu $F_{\text {tabel }}=1.84$. Jadi $F_{\text {hitung }}<F_{\text {tabel }}$ yakni 1.52 $<1.84$. Hal ini membuktikan bahwa subjek penelitian bersifat homogen.

\section{Pengujian Hipotesis}

Setelah $t_{\text {hitung }}$ diketahui, selanjutnya dikonsultasikan dengan harga $t$ tabel dengan derajat kebebasan $(\mathrm{df})=(\mathrm{N} 1+\mathrm{N} 2)-\mathrm{k}=(30$ $+30)-2=58$ dan taraf kesalahan $\alpha=5 \%$. Harga $\mathrm{t}$ df $=58$ dengan harga 2.01. karena $t_{\text {hitung }}$ diperoleh lebih besar dari $t_{\text {tabel }}$ yaitu $2.08>2.01$ maka hipotesis nihil $\left(\mathrm{H}_{0}\right)$ ditolak dan hipotesis alternatif $\left(\mathrm{H}_{\mathrm{a}}\right)$ diterima. Hal ini membuktikan bahwa model pembelajaran berbasis proyek dengan menggunakan media video berpengaruh dalam kemampuan menulis teks prosedur pada siswa.

\section{PEMBAHASAN}

\section{Temuan Penelitian}

Berdasarkan hasil penelitian di atas, maka diperoleh temuan penelitian sebagai berikut:

1. Kemampuan siswa dalam bercerita menggunakan media pembelajaran audio tergolong dalam kategori baik dengan nilai rata-rata sebesar $=76.86$

2. Kemampuan siswa dalam bercerita menggunakan media pembelajaran audiovisual tergolong dalam kategori baik dengan nilai rata-rata sebesar $=80.2$

3. Berdasarkan uji $\mathrm{t}$ diperoleh $\mathrm{t}_{0}=$ 2.08, kemudian dikonsultasikan dengan harga tabel $t$ dengan derajat kebebasan 
$(\mathrm{df})=30$ adalah 2.01 maka hipotesis nihil (H0) ditolak dan hipotesis alternatif (Ha) diterima. Hal ini membuktikan bahwa media audiovisual dengan audio berpengaruh terhadap kemampuan bercerita pada siswa kelas VII SMP Budi Murni 4 Medan .

\section{Pembahasan Hasil Temuan Penelitian.}

1. Perbedaan Kemampuan Bercerita Menggunakan Media Audio Siswa Kelas VII SMP Budi Murni 4 Medan .

Berdasarkan penelitian yang sudah dilaksanakan, maka diketahui kemampuan kemampuan bercerita menggunakan media audio di kelas kontrol dengan nilai rata-rata sebesar 76.86 dan termasuk dalam kategori baik dengan jumlah siswa sebanyak 30 orang. Adapun kategori pencapaian kemampuan bercerita tersebut termasuk ke dalam lima kategori yaitu kategori sangat baik sebanyak 3 siswa (10\%), kategori baik sebanyak 18 siswa (60\%), kategori cukup sebanyak 9 siswa (30\%), kategori kurang baik 0 siswa (0\%) dan kategori tidak baik sebanyak 0 siswa (0\%) atau tidak ada.

Penggunaan media pembelajaran audio kemampuan bercerita dengan baik dan nilai yang diperoleh siswa baik. Media pembelajaran audio merupakan suatu media bersuara ataupun bunyi yang berkaitan dengan materi pelajaran direkam dengan menggunakan alat perekam suara, kemudian hasil perekaman tersebut diperdengar kembali kepada peserta didik dengan menggunakan sebuah alat pemutarnya. Media audio merupakan media yang isi pesannya hanya diterima melalui indera pendengaran saja, untuk membantu proses pembelajaran, baik untuk pembelajaran massal, individual, maupun berkelompok. Melalui media ini informasi dapat disajikan dengan tepat, siswa dapat mengulang pembelajaran, siswa akan semakin lebih aktif, terfokus, termotivasi dan bekerja sama. Selain itu, kemampuan daya tangkap dan daya ingat lebih meningkat sehingga materi pembelajaran dapat berlangsung dengan baik.

2. Perbedaan Kemampuan Bercerita Menggunakan Media Audiovisual Siswa Kelas VII SMP Budi Murni 4 Medan .

Berdasarkan penelitian yang sudah dilaksanakan, maka diketahui kemampuan bercerita menggunakan media audiovisual yang diterapkan di kelas eksperimen, nilai rata-rata sebesar 80.2 dan tergolong kategori baik dengan jumlah siswa sebanyak 30 orang. Adapun kategori pencapaian kemampuan menulis teks prosedur termasuk ke dalam lima kategori yaitu kategori sangat baik sebanyak 6 siswa (20\%), kategori baik sebanyak 21 siswa (60\%), kategori cukup sebanyak 3 siswa (10\%), kategori kurang baik sebanyak 0 siswa (0\%), dan kategori tidak baik sebanyak 0 siswa (0\%) atau tidak ada.

Penggunaan media pembelajaran audiovisual kemampuan bercerita dengan baik dan nilai yang diperoleh siswa baik. Media pembelajaran audiovisual merupakan media perantara atau penggunaan materi dan penyerapannya melalui pandangan dan pendengaran sehingga membangun kondisi yang dapat membuat siswa mampu memperoleh pengetahuan, keterampilan, atau sikap. Manfaat menggunakan media audiovisual dalam pembelajaran adalah mempermudah dalam menyampaikan dan menerima pembelajaran atau informasi serta dapat menghindarkan salah pengertian, dan tidak membosankan, maksudnya ialah karena sifatnya yang variatif, siswa dalam pembelajaran tidak merasa bosan, karena sifatnya yang beragam film, tiga dimensi atau empat dimensi, dokumenter dan yang lainnya. Hal ini dapat menciptakan sesuatu yang variatif tidak membosankan para siswa.

3. Perbedaan Kemampuan Bercerita Menggunakan Media Audiovisual Dengan Audio Siswa Kelas VII SMP Budi Murni 4 Medan .

Sesuai dengan hasil analisis data dan temuan penelitian, dijelaskan bahwa penggunakan media pembelajaran audiovisual dengan audio berpengaruh signifikan terhadap pembelajaran kemampuan bercerita. Dikatakan berpengaruh karena dengan menggunakan media pembelajaran ini gurunya lebih banyak memperhatikan siswa, menuntut siswa untuk fokus pada penjelasan dan objek yang dijelaskan dan diperagakan dalam video sehingga siswa lebih aktif karena mengamati langsung proses atau langkah-langkah dalam video yang dapat diulang-ulang sampai benar-benar mengerti.

Hal ini terlihat dari perolehan nilai menggunakan media pembelajaran audio, rata-rata 76.86 dan nilai rata-rata tanpa menggunakan model pembelajaran berbasis proyek dengan media video 80.2. Dalam kegiatan bercerita, siswa dapat mengulang- 
ulang video tentang penjelasan menulis teks prosedur, sehingga siswa lebih mudah memahami dan termotivasi dalam proses belajar dan memudahkan mereka menuliskan yang tepat.

Dari penelitian yang sudah dilaksanakan, maka dapat disimpulkan bahwa hasil belajar siswa dengan menggunakan media audiovisual lebih mampu menceritakan kembali, berdasarkan media film yang ditayangkan dan diputar, dengan menggunakan indera penglihatan, dan pendengaran dibandingkan menggunakan media audio (suara) berdasarkan hasil pengamatan. Selanjutnya, mereka juga dapat mengamati dan mengulang kembali video yang dijelaskan sehingga siswa akan lebih aktif, peka terhadap materi yang disampaikan dan mampu menuangkan dalam tulisan serta durasi ingatan otak akan tersimpan lebih lama

\section{SIMPULAN}

Berdasarkan hasil penelitian tentang perbedaan kemampuan bercerita menggunakan media audiovisual dengan audio siswa kelas VII SMP Budi Muni 4 Medan .

1. Kemampuan bercerita siswa kelas VII SMP Budi Murni 4 Medan menggunakan media audiovisual diperoleh penyebaran 70 sampai 92 dengan nilai rata-rata 80.2 dan berada dalam kategori baik.

2. Kemampuan bercerita siswa kelas VII SMP Budi Murni 4 Medan menggunakan media audio diperoleh penyebaran 66 sampai 88 dengan nilai rata-rata 76.86 dan berada dalam kategori baik.

Hasil belajar siswa menggunakan media audiovisual dengan audio dalam kemampuan bercerita. Berdasarkan hasil uji hipotesis maka dapat disimpulkan bahwa $t_{\text {hitung }}$ diperoleh lebih besar dari $t_{\text {tabel }}$ yaitu $2.08>2.01$ artinya hipotesis nihil (Ho) ditolak dan hipotesis alternatif (Ha) diterima..

\section{SARAN}

Berdasarkan pembahasan dan simpulan dari hasil penelitian di atas, maka penulis memberikan beberapa saran yaitu:

1. Dalam hal pembelajaran kemampuan bercerita kiranya guru Bahasa Indonesia dapat menerapkan penggunaan media audiovisual dengan audio, karena penggunaan media pembelajaran audiovisual dengan audio ini berpengaruh dalam meningkatkan kemampuan siswa karena dengan media ini siswa dapat termotivasi dan perhatian mereka terfokus pada materi yang dipelajari. Oleh karena itu, para guru hendaknya mempersiapkan materi dan pemilihan media pembelajaran yang akan digunakan sebelum melaksanakan proses pembelajaran di kelas, karena dengan mempersiapkan materi dan media pembelajaran yang telah direncanakan dengan baik, maka pembelajaran akan berlangsung lebih efektif dan terarah sehingga tujuan pembelajaran dapat tercapai.

2. Guru Bahasa Indonesia hendaknya dapat menggunakan media pembelajaran yang efektif atau sesuai dengan materi pelajaran yang disampaikan, sehingga pembelajaran menarik bagi siswa dan mereka tidak merasa bosan.

3. Siswa disarankan agar lebih aktif dan serius lagi dalam mengikuti proses pembelajaran yang berlangsung.

4.

\section{DAFTAR PUSTAKA}

Agustin, Phibi Kristina. 2012. "Analisis Arsyad, Azhar. 2017. Media Pembelajaran. Jakarta : Rajagrafindo Persada.

Arsjad, Maidar G dan Mukti U.S. 1993. Pembinaan Keterampilan Berbicara Bahasa Indonesia. Jakarta: Erlangga.

Arikunto, Suharsimi. 2016. Prosedur Penelitian Suatu Pendekatan Praktik. Jakarta : Rineka Cipta.

Bimo. 2009. Teknik Bercerita Untuk Anak Usia Dini. http: badkomergangsan. wordpress.com. (diunduh 7 Maret 2019)

Brata. 2010. Peningkatan Keterampilan Berbicara.

http:mbahbrataedu.blogspot.com. (diunduh 14 April 2019).

Dhietria. 2009. Pemanfaatan Alat Peraga untuk Meningkatkan Kemampuan Bercerita Siswa dalam Pembelajaran Bahasa Indonesia dengan Pendekatan Contextual Teaching and Learning (CTL) pada Sekolah Menengah Pertama.http:dhietria.wordpress.c om(diunduh 15 April 2019).

Farida Tizen, Della. 2008. Teknik Bercerita dalam Bimbingan Konseling. Dalam 
http:ellafaridatizen.wordpress.co

$m$. (Diunduh 1 Okteber 2010).

Fitrianto, Anggit. 2009. Keterampilan Barbicara. www.blogger.com. (diunduh 3 Maret 2019).

Marwiyah. $2007 . \quad$ Peningkatan Pembelajaran Berbicara dengan Media Audio Visual di SMK N 8 Bandung. Skripsi. FBS:Unnes.

Tarmizi. 2009. Penerapan Teknik Cerita Berantai untuk Meningkatkan Kemampuan Berbicara Siswa. http://tarmizi.wordpress.com (diunduh 4 Maret 2019).

Tarigan, Djago, Tien Martini, dan Nurhayati Sudibyo. 1998. Pengembangan Keterampilan Berbicara: Depdikbud.

Tarigan, Henry Guntur. 1983. Berbicara sebagai Suatu Keterampilan Berbahasa. Jakarta: Angkasa.

Sadiman, Arief S. dkk. 2005. Media Pendidikan Pengertian, Pengembangan, dan Pemanfaatannya. Jakarta: Pustekkom Dikbud dan PT. Raja Grafindo Persada.

Sudijono. 2014. Pengantar Statistik Pendidikan. Jakarta: Rineka Cipta.

Sudjana, Nana dan Rivai, Ahmad. 2003. Teknologi Pengajaran. Bandung : CV Sinar Baru.

Sudjana, Nana. 1991. Dasar-Dasar Proses Belajar Mengajar. Bandung: Sinar Baru.

Sudjana, Nana. 2005. Dasar-dasar Proses\Belajar Mengajar. Bandung. Sinar Baru Algensindo.

Widi,Colin. 2009. Dasar-Dasar Berbicara. http:putrychan.wordpress.com (diunduh 3 Mei 2019).

Yuniawan, Tomi. 2002. Berbicara I/Retorika. Semarang: Unnes 